\title{
Replication of hepatitis $C$ virus in cell culture
}

\author{
S. L. Rybalko, Yu. I. Porva, I. P. Alekseenko, S. T. Diadiun, M. P. Zavelevych, \\ V. M. Borovykov, L. A. Popova, D. B. Fedorchenko \\ Public Institution L. V. Gromashevskyi Institute of Epidemiology and Infectious Diseases AMS of Ukraine \\ 5 Mykola Amosov str, Kyiv, Ukraine, 03038 \\ butenko@onconet.kiev.ua
}

\begin{abstract}
The technique for replicating hepatitis $C$ virus (HCV) in cell culture has been modified and the susceptibility of the cells of various origin to HCV upon their infection with HCV-containing sera has been compared. The viral load on the fifth day post-infection has been assessed by reverse transcriptase polymerase chain reaction technique. The highest infection and replication efficacy have been found in cells of rat Gasser's ganglion neurinoma. The peculiar features of the mitotic index and the anomalous forms of the mitosis have been studied in HCV-infected cells. The data presented may be used as a basis for the experimental model of $H C V$ infection in vitro suitable for studying the effects of antiviral drugs on the infection caused by the cytopathogenic variant of $\mathrm{HCV}$.
\end{abstract}

Keywords: hepatitis C virus (HCV), culture technique, cell culture.

Introduction. Hepatitis $\mathrm{C}$ virus (HCV) is the etiologic agent of hepatitis C. HCV-associated liver lesions are known to progress frequently to cirrhosis, which can lead to liver failure and hepatocellular carcinoma [1]. $\mathrm{HCV}$ is an enveloped single-stranded, positive sense RNA virus of Flaviviridae family with highly heterogeneous RNA [2]. The lack of the appropriate systems of HCV replication in vitro is the major obstacle delaying the development of anti-HCV drugs.

In the last few years, several cell culture systems suitable for HCV replication have been described that are based on the infection of primary cell cultures or cell lines or the cultivation of primary cells from chronically infected patients [3]. However, thus far these systems suffer from poor reproducibility and a low level of HCV replication that can be measured only with highly sensitive techniques such as PCR.

\footnotetext{
(C) S. L. RYBALKO, Yu. I. PORVA, I. P. ALEKSEENKO, S. T. DIADIUN,

M. P. ZAVELEVYCH, V. M. BOROVYKOV, L. A. POPOVA, D. B. FEDORCHENKO, 2009
}

Most attempts to replicate $\mathrm{HCV}$ in vitro have been undertaken with cell lines of human origin $[4,5]$. Tand B-cell lines selected for high permissiveness for $\mathrm{HCV}$ replication have been derived from T-cell lines MT-2 and MOLT-4, and B-cell line Daudi. MT-2C cell clone was described that supports HCV replication for up to 198 days post-infection [6].

Recently, the cytopathogenic variant of $\mathrm{HCV}$ capable of replicating in high titer in cell cultures of various origins has been successfully isolated from the blood serum of $\mathrm{HCV}$-infected patients [7]. The cytopathogenic variant of $\mathrm{HCV}$ was identified by neutralization, hemagglutination inhibition with the specific antibodies, by ELISA, immunofluorescence, and diffuse precipitation in agar. RNA of the cytopathogenic $\mathrm{HCV}$ variant was identified as $\mathrm{HCV}$ genomic RNA in RT-PCR using the primers to 5'-NTR, to the sequences coding for nucleocapside protein as well as by sequencing the genome fragment coding for nucleocapside protein [7]. This study gave an impetus 
Table 1

Characteristics of $\mathrm{HCV}$-containing sera from hepatitis $C$ patients used in the study

\begin{tabular}{c|c|c}
\hline Sera N & HCV genotype & $\begin{array}{c}\text { Initial hepatitis C virus load in million } \\
\text { genome equivalents }\end{array}$ \\
\hline 1 & 2 & $0.01-0.1$ \\
2 & $1 \mathrm{~b}$ & $1-10$ \\
3 & $1 \mathrm{~b}$ & $0.1-1$ \\
4 & $3 \mathrm{a}$ & $1-10$ \\
5 & $1 \mathrm{~b}$ & $0.1-1$ \\
6 & $1 \mathrm{~b}$ & $0.1-1$ \\
\hline
\end{tabular}

to further research aimed at searching for novel cell cultures susceptible for HCV replication.

The aim of the present study was to modify the technique for culturing $\mathrm{HCV}$, to assess the susceptibility of various cell lines to $\mathrm{HCV}$ and to analyze the effects of different HCV samples on the proliferative activity and the mitotic patterns of the infected cells. In addition to the human cell lines of various histogenesis, several lines of non-human origin were also assayed as the models for HCV replication in vitro.

Materials and Methods. Cell lines. Cells of rat Gasser's ganglion neurinoma (NGUK) were obtained from the neurinoma of Gasser's ganglion of rat induced by the transplacental administration of ethylnitrosourea [8]. ON-1 is the transplantable murine lymphoma cell line obtained upon co-culture of the cells of lymphoma induced by Bacillus megaterium $\mathrm{H}$. with the syngeneic embryonic fibroblasts [9]. Furthermore, the following leukemic cell lines obtained from Cell Culture Depository of RE Kavetsky Institute of Experimental Pathology, Oncology and Radiobiology of the National Academy of Sciences of Ukraine were used in the study: MT-4 (T-cell acute lymphoblastic leukemia), Daudi (originated from Burkitt lymphoma), K-562 (originated from the blast crisis of the human chronic myelogenous leukemia). MT-4, Daudi, and K-562 cells were cultured in suspension. ON-1 and NGUK cells were grown as monolayer cultures. The murine and human primary embryonic cell cultures were prepared according to the conventional techniques. All cell lines were grown in
RPMI-1640 medium supplemented with $10 \%$ of fetal calf serum and $40 \mu \mathrm{g} / \mathrm{ml}$ of gentamicin.

$H C V$-containing samples. The sera of hepatitis $\mathrm{C}$ patients were used as the source of the virus. The sera varied by $\mathrm{HCV}$ genotype as well as the viral load measured by RNA content in genome equivalents assayed by PCR technique (table 1).

Inoculation of cells with HCV-containing samples. The structural peptides of $\mathrm{HCV}$ are known to be cleaved by cellular peptidases as well as by viral protease. Considering this fact, we treated the cells with TPCK trypsin (type XIII from the calf pancreas, Sigma Cat\#N-8642) prior to virus inoculation with the aim of improving the efficacy of virus infection (according to WHO methodical recommendations [10]). Pretreatment of cells was such as follows: the cell monolayer was washed thrice with DMEM medium containing $2 \mu \mathrm{g} / \mathrm{ml}$ of TPCK trypsin. Then the undiluted $\mathrm{HCV}$-containing serum was applied for 30 min in a volume of $0.2 \mathrm{ml}$. After washing off the non-absorbed virus, RPMI-1640 medium supplemented with $2 \%$ of fetal calf serum and $40 \mu \mathrm{g} / \mathrm{ml}$ of gentamicin was added. The cells were cultured for 7 days at the temperature of $36.5^{\circ} \mathrm{C}$. The medium was collected on the $5^{\text {th }}$ day post-infection. The virus was assayed by PCR technique.

$\mathrm{HCV}$ assay. HCV in culture medium was assayed and HCV genotype was established by PCR technique using Amplisense HCV-Monitor-FRT test-system (Russia) according to the instruction of the manufacturer. The amplified DNA was tittered for the quantitative assessment of the viral load.

Infectious titer of $\mathrm{HCV}$. The infectious titer of $\mathrm{HCV}$ was assessed by infecting NGUK cells with serial ten-fold HCV dilutions. The virus was detected on the $5^{\text {th }}$ day post-infection by PCR technique. The infectious titer was considered as the positive one when at least 5 genome-equivalents of RNA HCV was detected by RT-PCR technique.

Reaction of neutralization. Neutralization in each dilution was assayed by the conventional technique [11] in NGUK, MT-4, or ON-1 cells. HCV at a dose of $100 \mathrm{ID}_{50}$ was neutralized by sera in different dilutions ranging from 1:20 to 1:640 by incubating them with the virus-containing culture medium for 1 hour. As anti-HCV antisera, the heat-inactivated sera of 
Table 2

RT-PCR detection of HCV on $5^{\text {th }}$ day post-infection of NGUK, MT-4, ON-1, Daudi and K-562 cells with HCV-containing sera of patients (in thousand genome-equivalents)

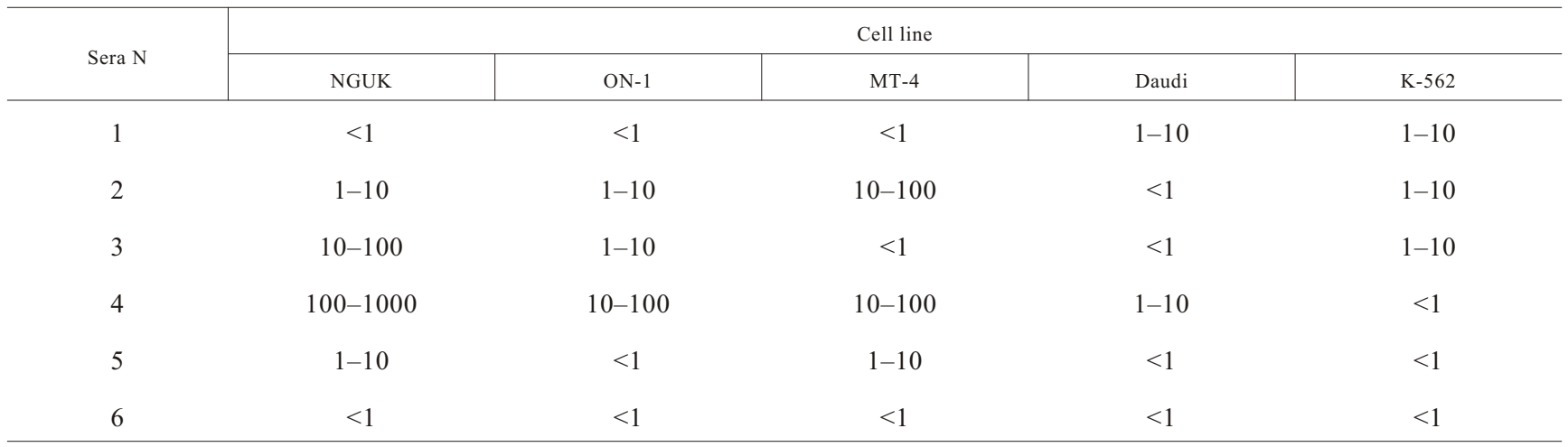

hepatitis $\mathrm{C}$ patients containing anti-HCV antibodies at the titer of 1:1000 and lacking HCV RNA were used. The mixture of virus and sera was added to the appropriate cultures in triplicates for each dilution. The cells were cultured at the temperature of $36.5^{\circ} \mathrm{C}$ in gas mixture containing $5 \% \mathrm{CO}_{2}$. The assay was performed by PCR technique.

Analysis of proliferative activity and anomalous mitoses. The mitotic index was calculated by counting the number of mitosis in 3,000-10,000 cells and expressed as the number of mitoses per 1,000 cells (\%o) [12]. The proliferative activity was assessed as a ratio of the mitotic index in virus-infected cell cultures to the mitotic index in the intact cultures (proliferation ratio). At the same time, the pathologic forms of mitosis were taken into account according to the classification elaborated by V. N. Bliumkin [12]. The ratio of the anomalous mitosis percentage in infected cells to the anomalous mitosis percentage in intact cultures was taken as the damaging ratio.

Electron microscopy. The samples of virusinfected cells for electron microscopy were prepared according to the conventional techniques [13]. Namely, MT-4 cells infected with HCV were fixed with $3 \%$ glutaraldehyde, the cells were pelleted at $15,000 \mathrm{~g}$. The pellet was mixed in $4 \% \mathrm{OsO}_{4}$ solution prepared in $0.15 \mathrm{M}$ phosphate buffer $(\mathrm{pH} 7.2-7.4)$ for 4 hours at room temperature. The preparation was dehydrated in the series of alcohol solutions of the increasing alcohol content (from $10 \%$ to absolute ethanol) followed by acetone treatment. Then the cells were embedded in Epon-Araldit mixture in the gelatinous capsule. The ultrathin sections were prepared using UMPP-5 ultramicrotome. For contrast enhancement, the samples were pretreated with $\mathrm{OsO}_{4}$ and $2 \%$ uranyl acetate in $70 \%$ ethanol. The samples were then examined in the transmission electron microscope EMV-100L.

Viruses. For the comparative analysis of the proliferative and damaging activities of $\mathrm{HCV}$ in the infected cells, the following strains of viruses were used in the study: Herpes simplex virus (HSV-2) - VN strain. The virus was maintained by serial passages in RK-13 cells with the infectious titer of 5.5-6.0 $\mathrm{lg}$ $\mathrm{TCD}_{50} / 0.1 \mathrm{ml}$. The virus-containing material was stored at the temperature of $-70{ }^{\circ} \mathrm{C}$.

Influenza virus $\mathrm{A} / \mathrm{FM} / 1 / 47$ (H1N1) with the infectious titer of 7.0-8.5 $\mathrm{lg} \mathrm{EID}_{50}$ in allantoic culture and hemagglutinin titer of 256-512 HAU/0.2 ml. Virus was adapted to mouse with the infectious titer of $4.0-5.5 \operatorname{lgLD}{ }_{50}$.

Results and Discussion. NGUK, MT-4, ON-1, Daudi, and K-562 cells were infected by HCVcontaining sera of the patients (see table 1). The results of PCR detection of HCV in the cultures on the $5^{\text {th }}$ day post-infection are given in table 2 . The most effective reproduction of $\mathrm{HCV}$ was evident in NGUK cells, therefore these cells seem to be more appropriate as the model for $\mathrm{HCV}$ reproduction in vitro. The stability of virus reproduction in cell cultures stated above has been proved by HCV detection in the following cell passages. 

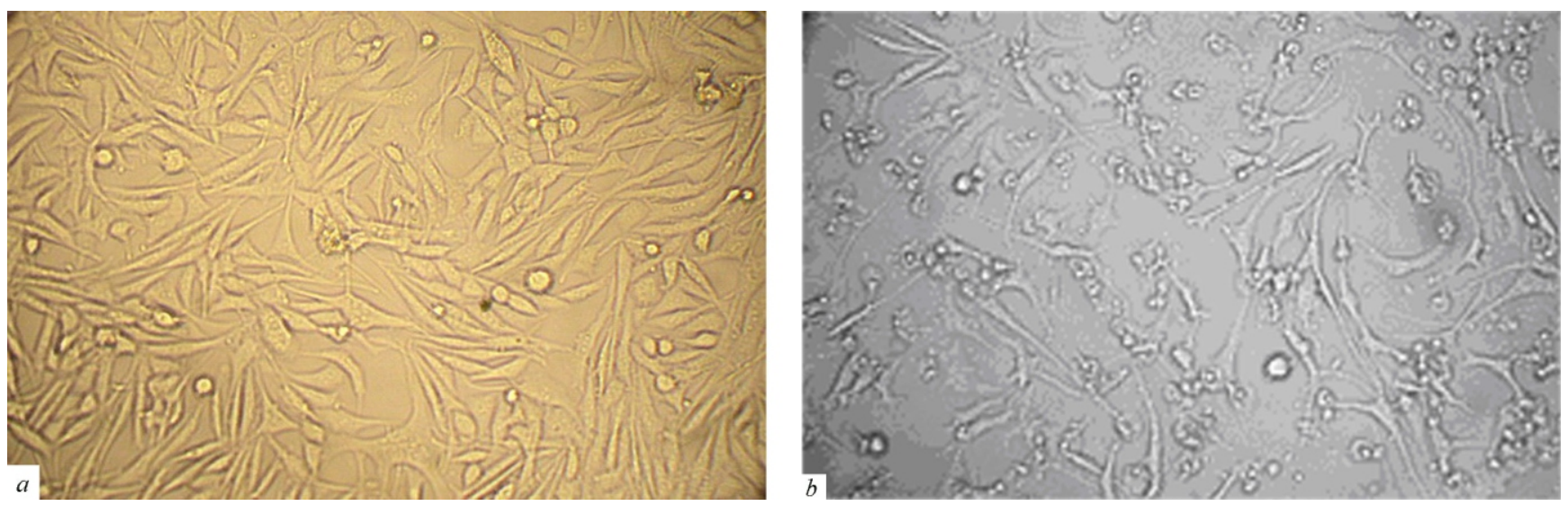

Fig. 1. Cytopathogenic effect of HCV in NGUK cells: $a$ - control cells; $b-\mathrm{HCV}$-infected cells $(\times 20)$

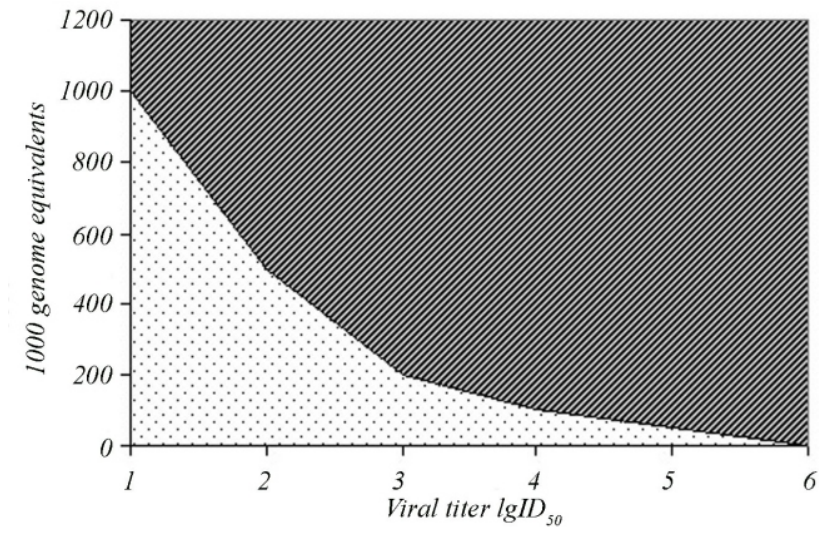

Fig. 2. Infectious titer of HCV (RT-PCR)

In general, the percentage of the HCV-positive infected cultures using TPCK trypsin pretreatment technique in all the cell lines assayed amounted to $100 \%$ as compared with about $68 \%$ in our previous studies employing the conventional technique of the infection without TPCK trypsin pretreatment [13]. Therefore, the modified isolation technique is advantageous in increasing substantially the percentage of the infected cell cultures in which HCV reproduction was maintained. Moreover, NGUK cells of non-human origin proved to be the most efficient for maintaining $\mathrm{HCV}$ replication in vitro.

The cytopathogenic effects of HCV in NGUK cells are demonstrated in fig. 1.

For ascertaining the infectivity of the isolated virus, we have titrated the virus from the infected culture in NGUK or ON-1 cells. The cells were infected with the dilutions of the virus ranging from $10^{-1}$ to $10^{-6}$, and the presence of $\mathrm{HCV}$ was confirmed in PCR. According to

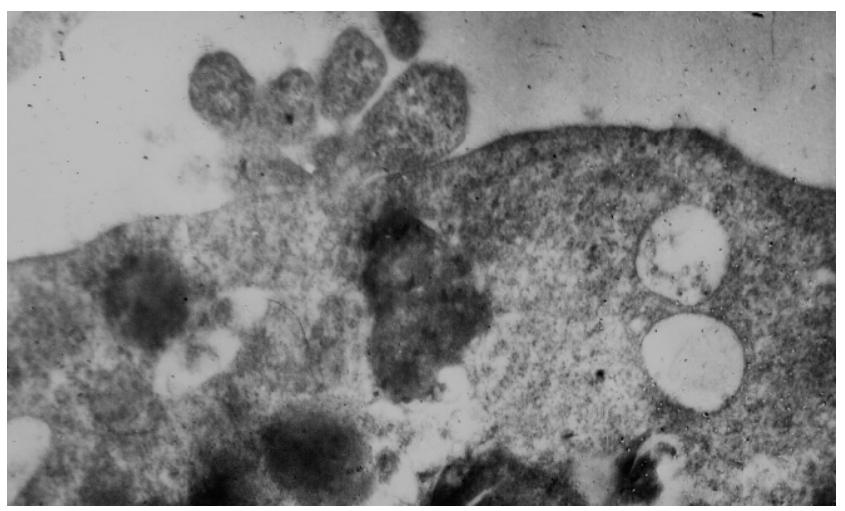

Fig. 3. Electronogram of MT-4 cells infected with HCV $(\times 15,000)$

the titration, the infectious titer of $\mathrm{HCV}$ was in 5-6 $\mathrm{lg}$ $\mathrm{ID}_{50}$. The typical titration results are given in fig. 2 .

Anti-HCV sera at the dilutions ranging from 1:20 to 1:640 neutralized completely the infectivity of the virus.

Electron microscopic examination of the sections of MT-4 cells infected with virus-containing cultural medium revealed the areas of cell membrane where the budding of the viral particles is evident. The morphology of the particles resembled that of Flaviviridae (fig. 3).

Since it is well known that HCV infection may result in increasing cell proliferation and consequently in liver cirrhosis and hepatocellular carcinoma, we have attempted to analyze the effect of the cultured $\mathrm{HCV}$ on the mitotic index [12].

As seen from the data presented in table $3, \mathrm{HCV}$ isolates from the patients in our study differed by their proliferation inducing and damaging activities in cell 
Table 3

Comparison of the effects of $H C V$, herpes simplex and influenza viruses on the mitotic activity in various cell lines

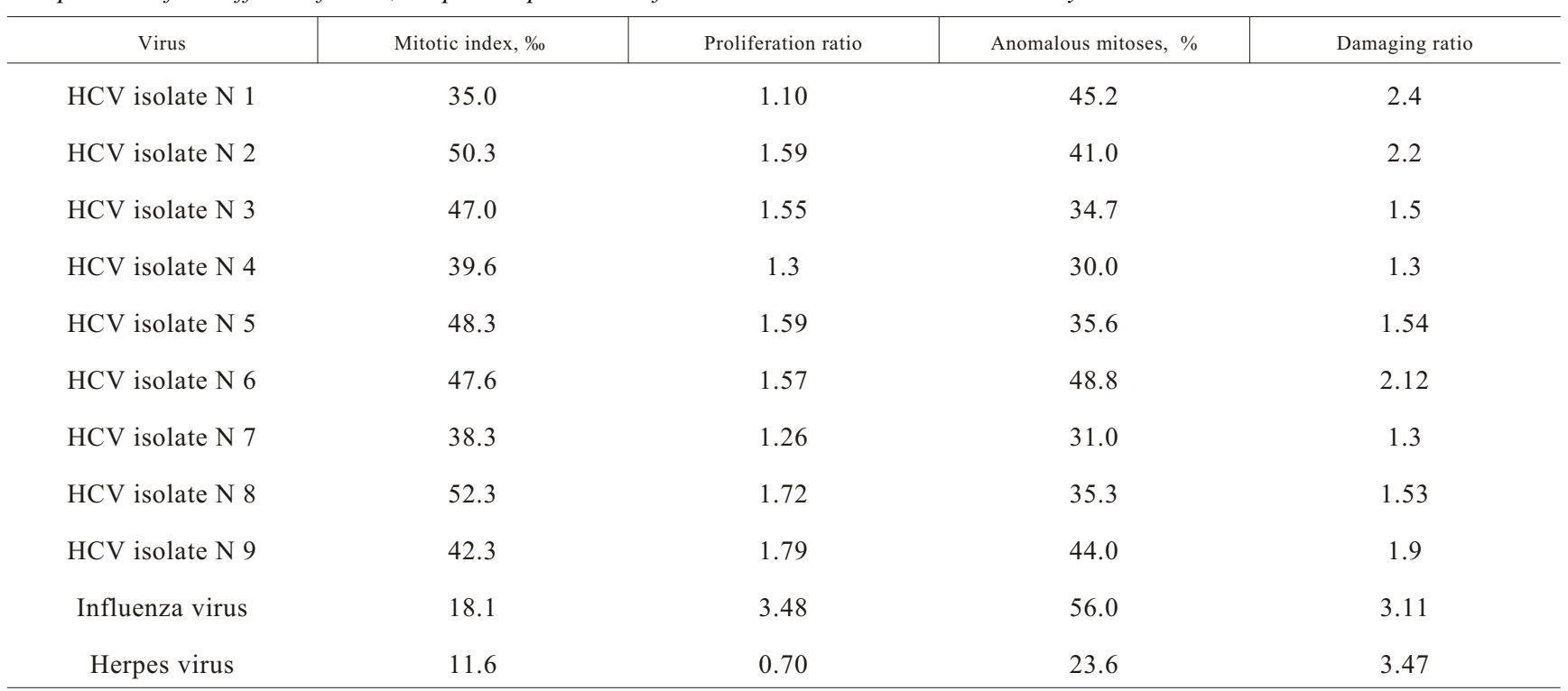

Proliferation ratio - a ratio of the mitotic index in virus-infected cell cultures to the mitotic index in the intact cultures; damaging ratio - ratio of the anomalous mitosis percentage in infected cells to the anomalous mitosis percentage in intact cultures. The intact NGUK cells were used as the controls for the analysis of HCV effects (the mitotic index in control cultures for each experiment was estimated individually). The murine and human primary embryonic cell cultures were used as controls for the analysis of influenza virus and herpes virus effects, respectively. The average mitotic index was $5.2 \%$ in murine embryonic cell cultures and $16.6 \%$ in human primary embryonic cell cultures.

cultures. The use of the indices characterizing the extent of cell proliferation and the damaging ratio (see table 3) allows us to delineate three types of the cell responses to $\mathrm{HCV}$. The first type is described by relatively high damaging effect judging by the ratio of anomalous mitoses to that in non-infected cultures (high damaging ratio, which is characteristic of isolate $\mathrm{N}$ 1, for example). Other type is characterized by relatively low damaging effect and high proliferative effect (such as in isolate N 8). Finally, several HCV isolates have intermediate damaging and proliferative effects on the infected cells (see table 3 ).

Nevertheless, in all HCV isolates under study the mitotic activity caused by HCV was inferior to that of influenza virus. Moreover, the relative damaging effect of $\mathrm{HCV}$ was also lower as compared with that of influenza virus and herpes virus, the latter being the typical representatives of the classical acute and persistent infections, respectively.

To summarize, the modified technique of $\mathrm{HCV}$ culture employing the cleavage of the surface proteins with TPCK trypsin has resulted in substantial increase in the percentage of the effective $\mathrm{HCV}$ isolation. The use of this technique and the wide range of the cells of various origins allow us to broaden the spectrum of the susceptibility to $\mathrm{HCV}$ in vitro. NGUK cells of non-human origin turned out to be highly susceptible for maintaining $\mathrm{HCV}$ reproduction. HCV reproduction was confirmed by RT-PCR technique and in neutralization reaction. In the cells infected with HCV-containing sera the particles morphologically resembling flaviviruses were revealed by the electron microscopy.

The analysis of the different HCV isolates makes it possible to reveal several patterns of the shifts in mitotic index and the induction of the anomalous forms of mitosis in cells exposed to HCV. The proliferative effects of the analyzed $\mathrm{HCV}$ isolates are inferior to that of the acute infectious viruses such as influenza virus. The index of HCV damaging effect is inferior to that of both influenza and herpes virus infection. Such characteristics of the cell response to HCV accounting for stimulation of proliferation as well as the damaging effects seem to reflect various stages of the clinical 
course of hepatitis $\mathrm{C}$ that may be advantageous for both prognosis and assessment of the treatment efficacy. These studies are underway now.

С. Л. Рибалко, Ю. І. Порва, І. П. Алексєєнко, С. Т. Дядюн,

М. П. Завелевич, В. М. Боровиков, Л. А. Попова,

Д. Б. Федорченко

Реплікація вірусу гепатиту С у культурі клітин

Резюме

Представлено модифікований метод культивування вірусу геnатиту C (ВГC) in vitro та результати порівняльного аналізу чутливості культур клітин різного походження до ВГС при їхньому інфікуванні ВГС-вмісними сироватками крові людини. За допомогою методу зворотнотранскриптазної полімеразної ланиюгової реакції визначено вірусне навантаження на n'яту добу культивування. Ефективність культивування була найвищоюю в культурі клітин невриноми гасерова вузла шура. Виявлено особливості впливу ВГС на мітотичний індекс і утворення аномальних форм мітозу. Результати роботи можуть стати основою для створення експериментальної моделі інфекиії ВГС in vitro, придатної для вивчення впливу антивірусних препаратів на інфекцію, викликану ичтопатогенним варіантом ВГС.

Ключові слова: вірус гепатиту С (ВГС), метод культивування, культура клітин.

С. Л. Рыбалко, Ю. И. Порва, И. П. Алексеенко, С. Т. Дядюн,

М. П. Завелевич, В. М. Боровиков, Л. А. Попова,

Д. Б. Федорченко

Репликация вируса гепатита С в культуре клеток

Резюме

Представлен модифицированный метод культивирования вируса гепатита С (ВГС) in vitro и результаты сравнительного анализа чувствительности к нему культур клеток разного происхождения при их инфицировании ВГС-содержащими сыворотками крови больных. Вирусную нагрузку на пятые сутки определяли с помощьью метода обратнотранскриптазной полимеразной иепной реакции. Эффективность культивирования вируса была наивыстей в культуре клеток невриномы гассерова узла крысы. Выявлены особенности воздействия ВГС на митотический индекс и образование аномальных форм митоза. Результаты работы могут стать основой для создания экспериментальной модели инфекции ВГС іп vitro, пригодной для изучения влияния антивирусных препаратов на инфекиию, вызванную ичитопатическим вариантом ВГС.

Ключевые слова: вирус гепатита С (ВГС), метод культивирования, культура клеток.

\section{REFERENCES}

1. Alter Y. J. To or not to C: these are questions // Blood.1995.-85.-P. 1681-1695.

2. Suzuki T., Aizaki H., Murakami K., Shoji I., Wakita T. Molecular biology of hepatitis C virus // J. Gastroenterol.2007.- 42.-P. 411-423.

3. Bartenschlager R., Lohmann V. Replication of hepatitis C virus // J. Gen. Virol.-2000.- 81.- P. 1631-1648.

4. Narovlianski A. N., Deriabin P. G., Vershinina M. Iu., Mezentseva M. V., Ershov F. I. Effect of interferon inductors on infection induced by hepatitis $\mathrm{C}$ virus and activity of mRNA cytokines in cell cultures SW-13 and MT-4 // Vopr. Virusol.-2002.-47.-P. 17-21 (in Russian).

5. Yohko K. S., Hiroshi Y. In vitro systems for the detection of hepatitis C virus infection // Viral Hepatitis Rev.-1995.1.-P. 59-65.

6. Mizutani T., Kato N., Saito S., Ikeda M., Sugiyama K., Shimotohno $K$. Characterization of hepatitis $\mathrm{C}$ virus replication in cloned cells obtained from a human T-cell leukemia virus type 1-infected cell line, MT-2 // J. Virol.-1996.-70.P. 7219-7223.

7. Deryabin P. G., Lvov D. K., Isaeva E. I. Biological properties of cytopathogenic hepatitis variants // $21^{\text {st }}$ Int. Congr. Virol.Sydney, 1999.-Vol. 13.-P. 2.

8. Chudinovskaia N. V., Poliakova G. P., Kondakova L. I. Effect of dimethylsulfoxide on the morphology and proliferation of the tumor NGUK-1 cell line // Biull. Eksp. Biol. Med.-1986.101.- P. 72-74 (in Russian).

9. Zatula D. H., Likhtenshtein V. E., Zmareva E. N., Zavelevich M. P., Verkhatskyi P. P. Morphology of transplantable coultures of mirine lymphoma induced by Bac. megaterium H. // Materials of III Ull-Union Conf. «Modern methods of morphological study in theoretical and practical oncology».-Tbilisi, 1983.-Vol. 1.-P. 118-119 (in Russian).

10. WHO manual on animal influenza diagnosis and surveillance. $\mathrm{WHO} / \mathrm{CDS} / \mathrm{CSR} / \mathrm{NCS} / 2002.5$.

11. Lukina R. N. Reaction of neutralization // Manual on laboratory diagnostics of viral and rickettsial diseases.-M.: Meditsina, 1965.-P. 146-158 (In Russian).

12. Bliumkin V. N., Zhdanov V. M. Effects of viruses on chromosomal apparatus and cell division.-M.: Meditsina, 1973.256 p. (in Russian).

13. Biel S. S., Gelderblom H. R. Electron microscopy of viruses // Virus cell culture - a practical approach / Ed. A. Cann.Oxford: Oxford Univ. press, 1999.-P. 111-147.

14. Rybalko S. L., Diadiun S. T., Dubrovskyi I. B., Belous F. A., Atamaniuk V. P., Honcharenko E. L., Abdullaieva M. V. Antiviral activity of Proteflazid preparation in the model of viral hepatitis C // Bioresourses and Viruses: Abstr. Int. Conf.Kyiv, 2004.-P. 48. 